\title{
PENGGUNAAN BAHAN AJAR STRUKTUR ALJABAR UNTUK MENINGKATKAN KEMAMPUAN PEMBUKTIAN MATEMATIS PADA MAHASISWA IKIP PGRI PONTIANAK
}

\author{
Jamilah $^{1}$, Syarifah Fadillah ${ }^{1}$ \\ ${ }^{1}$ Pendidikan Matematika, IKIP PGRI Pontianak \\ E-mail: jamilah.mtk2002@gmail.com
}

\begin{abstract}
This study aims to know the effect of teaching and learning using Algebraic Stucture materials based on mathematical proof to improve mathematical proof ability. The type of this study is experimental method with One Shot Case Study design. Population in this study is students of $6^{\text {th }}$ semester in Departement of Mathematics Education and sample is students in class $A$ and $B$ which are consist of 83 students. The results show that teaching and learning using Algebraic Structure materials based on mathematical proof can improve mathematical proof ability with $Z_{0 b s}=9,74>1,645=Z_{0,05}$. The total score of mathematical proof ability is 44,34 from 100 or 44,34\% (good). In each aspect, teaching and learning using Algebraic Stucture materials based on mathematical Proof can improve the ability to construct evidence includes the use of methods of proof and the use of fact, the concept and principles of mathematics by 26,99 from 50 or 53,98 $\%$ (good) and 17,14 from 50 or 34,70\% (good) in the aspect of the ability to read a proof to determine truth or mistake by seeing the correspondence between the system of axioms, premises, or theorems existing.
\end{abstract}

Keywords : algebraic structure material, mathematical proof ability

Belajar matematika di tingkat perguruan tinggi umumnya melibatkan kemampuan kognitif tingkat tinggi, seperti kemampuan analisis, sintesis, dan evaluasi, bukan sekedar mengingat pengetahuan faktual ataupun aplikasi sederhana dari berbagai formula atau prinsip. Belajar dan berpikir matematika di perguruan tinggi telah menjadi perhatian Committee on the Undergraduate Program in
Mathematics atau CUPM (Arnawa, 2006), yang merekomendasikan antara lain bahwa pembelajaran matematika di kelas harus melibatkan aktivitas yang mendukung semua mahasiswa untuk meningkatkan dan mengembangkan keterampilan penalaran analitis dan kritis, pemecahan masalah, dan komunikasi, dan mencapai kebiasaan (habit) berpikir matematis. Aktivitas tersebut 
dapat terlihat melalui proses pembuktian suatu konsep.

Tidak bisa dipungkiri bahwa sebagian mata kuliah yang ada di Program Studi Pendidikan Matematika menuntut mahasiswa untuk dapat membuktikan konsep matematika yang dipelajari. Salah satu mata kuliah tersebut adalah mata kuliah Stuktur Aljabar. Pembuktian memainkan peranan penting dalam struktur aljabar karena sarat dengan definisi, lema, dan teorema. Agar mahasiswa dapat memahami struktur aljabar dengan baik maka mahasiswa dituntut untuk dapat memahami setiap lema dan teorema yang dipelajari. Salah satu syarat agar hal tersebut tercapai adalah mahasiswa harus mempunyai kemampuan dalam membuktikan lema dan teorema yang dipelajari dan dapat membuktikan beberapa permasalahan yang terkait dengan penerapan definisi, lema, dan teorema. Dengan demikian, meningkatkan pemahaman mahasiswa dalam Struktur Aljabar dapat dilakukan melalui peningkatan kemampuan mahasiswa dalam pembuktian matematis Hal ini sesuai dengan yang disarankan oleh Hanna (dalam Arnawa, 2006) yang menyatakan bahwa pembelajaran matematika tanpa disertai dengan pembuktian tidak mencerminkan teori dan praktek bermatematika.

Reid (dalam Arnawa, 2006) mengatakan pembuktian membuat matematika unik dan berbeda dari disiplin ilmu lainnya. Melalui tugas pembuktian, dosen dapat melihat: (1) bagaimana kemampuan mahasiswa dalam beragumentasi secara logis, (2) bagaimana mahasiswa menggunakan contoh dan lawan contoh untuk mendukung argumentasinya, kelemahan-kelemahan apa saja yang dialami mahasiswa dalam bernalar, dan (4) miskonsepsi apa yang sering dialami mahasiswa.

Berdasarkan penelitian sebelumnya yang dilakukan oleh Fadillah \& Jamilah (2015), Struktur Aljabar merupakan mata kuliah yang sulit untuk dipelajari dan juga sulit untuk diajarkan. Dari sisi mahasiswa, kesulitan ini misalnya disebabkan oleh: (1) konsep-konsep dalam struktur aljabar sangat abstrak, (2) banyak contoh-contoh yang berkenaan dengan konsep, tidak dikenali dengan baik oleh mahasiswa, (3) banyak mahasiswa yang belum terbiasa dengan pembuktian deduktif. Salah satu penyebabnya adalah adanya anggapan mahasiswa yang memandang bukti formal sebagai permainan manipulasi lambanglambang matematika yang tak bermakna. Pandangan seperti inilah yang pada akhirnya membuat mahasiswa tak dapat memahami bukti yang sederhana sekalipun (Downs \& Downs, 2002).

$\begin{array}{r}\text { Upaya } \\ \text { meningkatkan }\end{array}$
pembuktian melakukan
kemampuan dilakukan dengan beberapa cara, diantaranya adalah penggunaan bahan ajar yang dapat mendukung terbentuknya kemampuan pembuktian matematis. Selain itu, dapat juga dilakukan suatu inovasi pembelajaran yang dapat memfasilitasi mahasiswa mengembangkan kemampuan pembuktian matematis tersebut. Pada penelitian sebelumnya, peneliti telah melakukan penelitian tentang pembuatan bahan ajar struktur aljabar yang dirancang untuk membantu mahasiswa dalam meningkatkan 
kemampuan pembuktian matematis dan pemahaman mahasiswa khususnya dalam pembuktianpembuktian lema dan teorema dari materi struktur aljabar, serta aplikasinya dalam pemecahan masalah. Hasil yang diperoleh menunjukkan bahwa kemampuan pembuktian matematis mahasiswa masih tergolong rendah. Hal ini disebabkan oleh bahan ajar struktur aljabar yang dibuat belum sepenuhnya mengakomodir terbentuknya kemampuan pembuktian matematis yang diharapkan (Fadillah \& Jamilah, 2015).

Permasalahan tersebut menjadi alasan bagi peneliti untuk kembali meningkatkan kemampuan pembuktian matematis dengan cara menerapkan bahan ajar struktur aljabar yang telah direvisi sesuai dengan catatan perbaikan pada penelitian sebelumnya.

\section{METODE}

Penelitian ini merupakan penelitian lanjutan dari proses pengembangan bahan ajar. Pada penelitian sebelumnya telah dikembangkan bahan ajar dengan menggunakan 4-D models dengan tahapan pengembangan: (1) pendefinisian, (2) perancangan, dan (3) pengembangan mulai dari validasi bahan ajar hingga uji coba penggunaan bahan ajar untuk melihat kemampuan pembuktian matematis mahasiswa (Thiagarajan, dkk, 1974). Pada penelitian ini, penulis melihat peningkatan kemampuan pembuktian matematis setelah diterapkan pembelajaran menggunakan bahan ajar Struktur Aljabar berbasis pembuktian matematis. Bahan ajar yang digunakan adalah bahan ajar yang telah dikembangkan dan telah diperbaiki. Oleh karenanya, metode penelitian yang digunakan adalah metode penelitian eksperimen dengan bentuk Pre Experimental Design. Lebih khusus, penelitian ini menggunakan rancangan One Shoot Case Study. Adapun rancangan penelitian ini dapat dilihat pada Gambar 1.

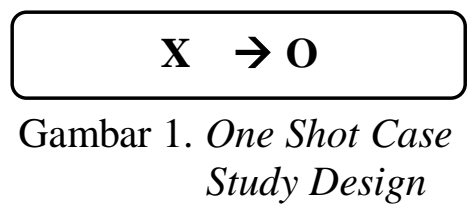

dengan

$\mathbf{X}$ : perlakuan dengan memberikan pembelajaran menggunakan bahan ajar berbasis pembuktian matematis (variabel bebas) $\mathbf{O}: \begin{aligned} & \text { kemampuan pembuktian } \\ & \text { matematis (variabel terikat) }\end{aligned}$

Dalam desain penelitian ini, hanya terdapat satu kelompok yang diberi pembelajaran menggunakan bahan ajar berbasis pembuktian matematis. Terdapat dua variabel dalam penelitian ini, yaitu variabel independen (pembelajaran menggunakan bahan ajar berbasis pembuktian matematis) dan variabel dependen (kemampuan pembuktian matematis mahasiswa) (Sugiyono, 2012).

Populasi dalam penelitian ini adalah mahasiswa semester VI program studi Pendidikan Matematika IKIP PGRI Pontianak yang terdiri 4 kelas. Sedangkan sampel penelitian yang dipilih adalah 2 kelas yang terdiri dari 84 mahasiswa. Prosedur dalam penelitian ini dapat dilihat pada Diagram 1. 


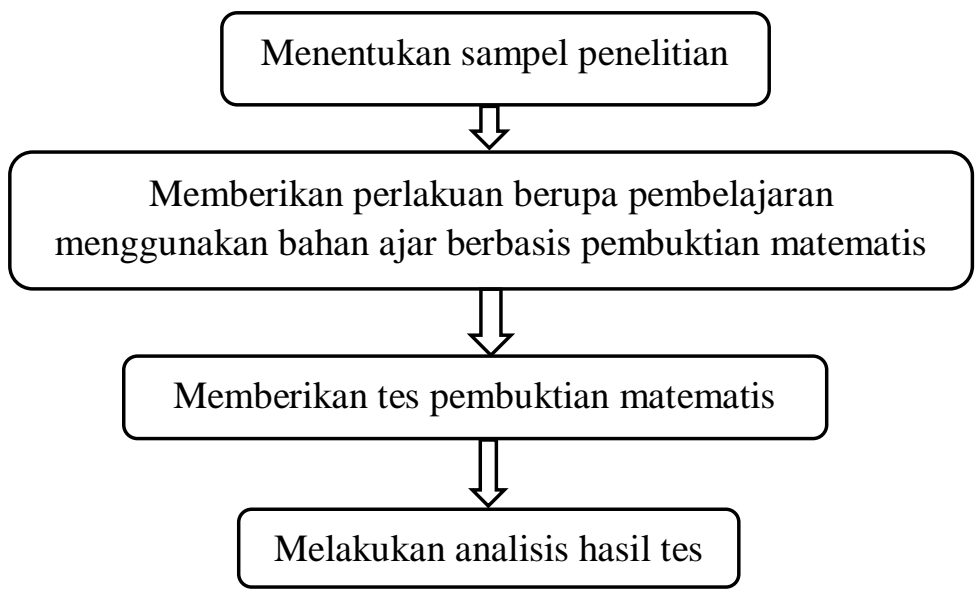

Diagram 1. Prosedur penelitian

Teknik pengumpulan data yang digunakan dalam penelitian ini adalah teknik pengukuran dengan alat pengumpul data adalah tes pembuktian matematis untuk mengukur kemampuan pembuktian matematis mahasiswa. Data dianalisis menggunakan statistik inferensial dan deskriptif. Prosedur analisis data dilakukan dalam dua tahap, yaitu:

1. Pada analisis data menggunakan statistik inferensial, data hasil tes pembuktian matematis keseluruhan dianalisis menggunakan uji hipotesis untuk menentukan apakah pembelajaran menggunakan bahan ajar Struktur Aljabar berbasis pembuktian matematis dapat meningkatkan kemampuan pembuktian mahasiswa dari nilai rata-rata tahun sebelumnya sebesar 14,13 . Hipotesis dalam penelitian ini terdiri dari:

$H_{0}: \mu \leq 14,13$ (pembelajaran menggunakan bahan ajar Struktur Aljabar berbasis pembuktian matematis tidak dapat meningkatkan kemampuan pembuktian matematis) dan $H_{1}$ : $\mu>14,13$ (pembelajaran menggunakan bahan ajar Struktur Aljabar berbasis pembuktian matematis dapat meningkatkan kemampuan pembuktian matematis). Statistik uji yang digunakan adalah uji rerata dengan rumus $Z=\frac{\nexists-\mu_{0}}{\sigma / \sqrt{n}} \sim N(0,1)$ dengan $\alpha=0,05$.

2. Pada analisis data menggunakan statistik deskriptif, dilakukan langkah-langkah sebagai berikut: (1) melakukan penskoran terhadap hasil tes pada masingmasing aspek pembuktian matematis dengan menggunakan rumus $\bar{X}=\frac{\sum x}{n}$ dengan $\bar{X}$ : skor rata-rata, $\sum X$ : jumlah skor semua subjek penelitian, $n$ : banyak sampel penelitian; (2) mengkategorikan kemampuan pembuktian matematis dengan kriteria seperti pada Tabel 1. Dan (3) melakukan deskripsi hasil tes untuk masing-masing aspek pembuktian matematis. 
Tabel 1. Kriteria kemampuan pembuktian matematis

\begin{tabular}{ll}
\hline Interval Persentase & Kriteria \\
\hline $0 \% \leq P<30 \%$ & Jelek \\
\hline $30 \% \leq P \leq 70 \%$ & Baik \\
\hline $70 \%<P \leq 100 \%$ & Sangat baik \\
\hline
\end{tabular}

\section{HASIL DAN PEMBAHASAN}

Kemampuan pembuktian matematis mahasiswa ini diukur melalui tes pembuktian matematis yang terdiri dari 2 aspek penilaian, meliputi; (1) kemampuan mengkonstruksi bukti meliputi penggunaan metode-metode pembuktian dan penggunaan fakta, konsep, dan prinsip matematika, (2) kemampuan membaca suatu pembuktian untuk menentukan kebenaran atau kekeliruannya dengan melihat kesesuaian antara sistem aksioma, premis, atau teorema yang sudah ada, serta kemampuan dalam melengkapi pembuktian (Shelden \& Shelden, 2003). Materi struktur aljabar yang diujikan adalah materi operasi biner, grup, dan subgrup.

Berdasarkan hasil perhitungan skor tes pembuktian matematis diperoleh skor rata-rata kemampuan pembuktian matematis mahasiswa sebesar 44,43 dari skor total 100 atau sebesar 44,43 \%. Dan berdasarkan hasil uji hipotesis diperoleh nilai $Z_{\text {0bs }}=9,74>1,645=Z_{0,05} . \quad$ Ini menunjukkan bahwa $H_{0}$ ditolak. Ini berarti bahwa pembelajaran menggunakan bahan ajar Struktur Aljabar berbasis pembuktian matematis dapat meningkatkan kemampuan pembuktian matematis dari skor sebelumnya 14,13 atau sebesar $18,84 \%$. Ini juga menunjukkan bahwa terdapat peningkatan hasil kemampuan pembuktian matematis sebesar 25,50 $\%$. Hasil penskoran pada masingmasing indikator kemampuan pembuktian matematis dapat dilihat pada Tabel 2.

Tabel 2. Rangkuman kemampuan pembuktian matematis

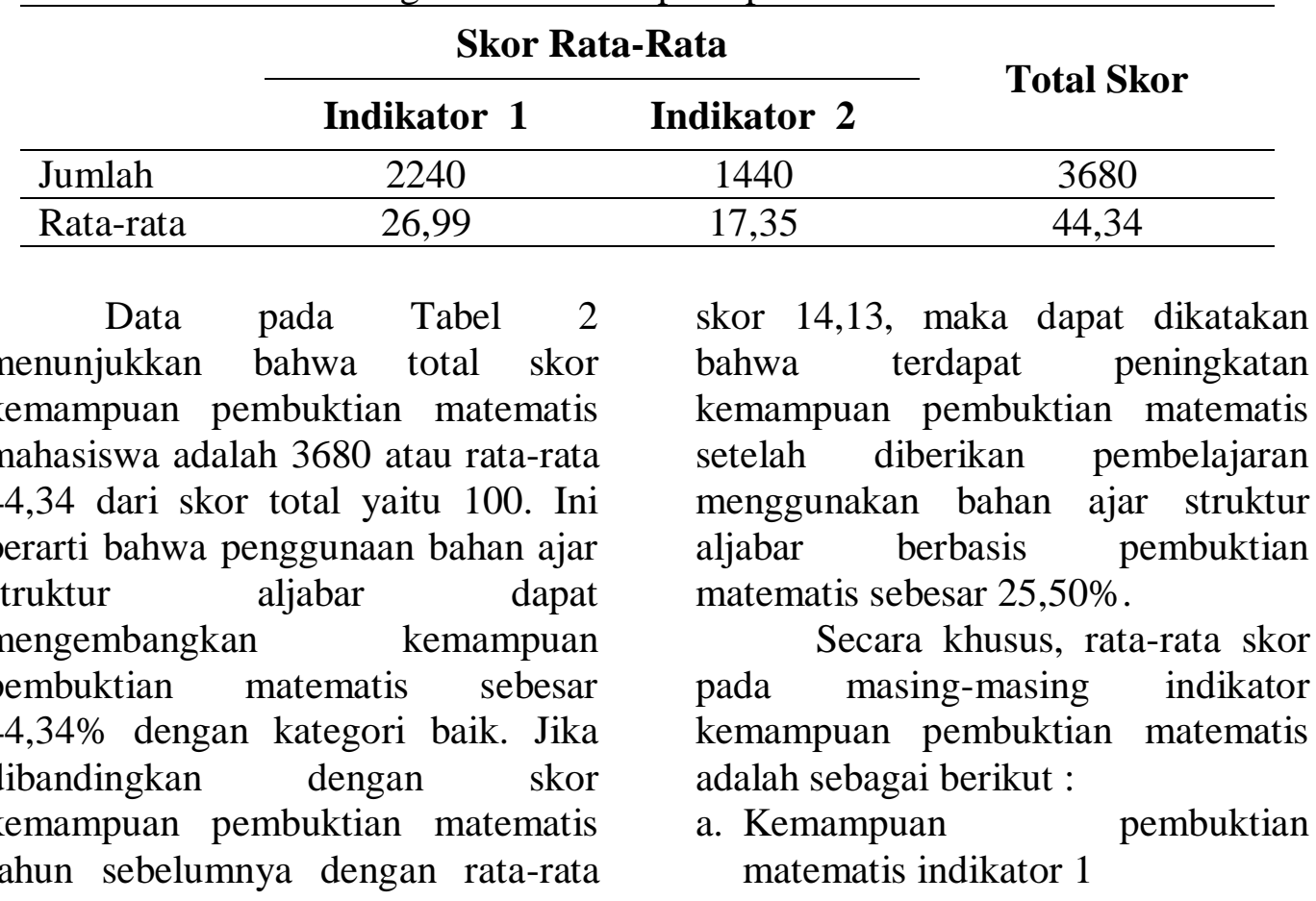


Pada kemampuan pembuktian matematis indikator 1 diperoleh rata-rata skor 26,99 dari skor total 50. Hasil ini menunjukkan bahwa penggunaan bahan ajar struktur aljabar berbasis pembuktian matematis dapat mengembangkan kemampuan pembuktian matematis pada indikator kemampuan mengkonstruksi bukti meliputi penggunaan metode-metode pembuktian dan penggunaan fakta, kosep, dan prinsip matematika sebesar 53,98\% dengan kategori baik.

b. Kemampuan matematis indikator 2 . Pada pembuktian

pembuktian matematis indikator 2

kemampuan diperoleh rata-rata skor 17,35 dari skor total 50. Hasil ini menunjukkan bahwa penggunaan bahan ajar struktur aljabar berbasis pembuktian matematis dapat mengembangkan kemampuan pembuktian matematis pada indikator kemampuan membaca suatu pembuktian untuk menentukan kebenaran atau kekeliruannya dengan melihat kesesuaian antara sistem aksioma, premis, atau teorema yang sudah ada serta melengkapi pembuktian dengan skor sebesar $34,70 \%$ dengan kategori baik.

Hasil penelitian yang diperoleh menunjukkan bahwa penggunaan bahan ajar struktur aljabar berbasis pembuktian matematis dalam meningkatkan kemampuan pembuktian matematis dinilai baik. Hal ini terlihat dari hasil uji hipotesis yang menunjukkan bahwa pembelajaran berbantuan bahan ajar berbasis pembuktian matematis dapat meningkatkan kemampuan pembuktian matematis dengan skor rata-rata 44,34 dari skor total 100 atau sebesar $44,34 \%$. Sama halnya dengan skor yang diperoleh mahasiswa pada masing-masing indikator kemampuan pembuktian matematis. Pada indikator pertama, skor kemampuan pembuktian matematis yang dapat dikembangkan dari penggunaan bahan ajar struktur aljabar berbasis pembuktian matematis sebesar 26.99 atau 53,98\% dengan kategori baik. Sedangkan pada indikator kedua, skor kemampuan pembuktian matematis yang dapat dikembangkan dari penggunaan bahan ajar struktur aljabar berbasis pembuktian matematis sebesar 17,35 atau 34,70\% dengan kategori baik.

Meskipun hasil tes kemampuan pembuktian matematis menunjukkan bahwa kedua indikator pembuktian matematis tergolong baik, namun hasil tes kemampuan pembuktian matematis secara keseluruhan masih belum mencapai keberhasilan lebih dari 50\% dari skor maskimal. Selain itu, hasil tes kemampuan pembuktian matematis pada masing-masing indikator juga menunjukkan perbedaan rata-rata skor yang cukup signifikan. Pada indikator pertama diperoleh rata-rata skor 26.99, sedangkan pada indikator kedua diperoleh rata-rata skor sebesar 17,35. Hal ini menunjukkan bahwa mahasiswa terlihat lebih sulit dalam menyelesaikann permasalahan pada indikator kedua. Dengan melihat hasil pengerjaan mahasiswa terhadap soal tes pembuktian matematis yang diberikan, diperolehlah beberapa hal yang menunjukkan masih lemahnya mahasiswa dalam menyelesaikan soal tes pembuktian matematis, khususnya pada indikator kedua. 
Masalah 1. Misalkan $G=\{2,4$, $6,8\}$ dengan operasi perkalian bilangan modulo 10, maka buktikan apakah $(G, X)$ merupakan grup siklik?

Gambar 1. Masalah untuk mengukur indikator 1

Pada masalah 1, mahasiswa diberikan suatu permasalahan untuk menentukan apakah suatu himpuan dengan sebuah operasi biner merupakan grup siklik atau bukan. Melalui masalah ini, mahasiswa diharapkan dapat menentukan terlebih dahulu apakah $(G, \times)$ merupakan grup atau bukan. Dari hasil pengerjaan mahasiswa, masih terdapat beberapa mahasiswa yang tidak menunjukkan hal tersebut. Selain itu, pada masalah 1 ini, mahasiswa pada umumnya keliru dalam menentukan elemen indentitas di $G$ dan invers untuk setiap elemen di $G$. Mahasiswa beranggapan bahwa $e=1 \in G$, dengan $e$ merupakan elemen identitas di $G$. Padahal $1 \notin G$. Kekeliruan dalam penentuan elemen identitas akan berdampak pada kekeliruan pada penentuan invers untuk setiap elemen. Hal ini terjadi disebabkan karena belum maksimalnya mahasiswa memahami konsep yang didapat ketika proses belajar-mengajar berlangsung, khususnya konsep tentang grup pada himpunan bilangan bulat modulo.

Masalah 2. Misalkan $\boldsymbol{G}$ adalah sebuah grup. Buktikan bahwa jika $\boldsymbol{b}^{-\boldsymbol{1}} \boldsymbol{a}^{-\mathbf{1}} \boldsymbol{b} \boldsymbol{\alpha}=\boldsymbol{e}$, untuk setiap $\boldsymbol{a}, \boldsymbol{b}$ anggota $\boldsymbol{G}$ maka $\boldsymbol{G}$ grup abelian!

Berikut ini adalah pembuktian dari pernyataan di atas:

$$
\begin{aligned}
b^{-1} a^{-1} b a & =\left(b^{-1} b\right)\left(a^{-1} a\right) \\
& =e e \\
& =e
\end{aligned}
$$

Karena $b^{-1} a^{-1} b a=\left(b^{-1} b\right)\left(a^{-1} a\right)$ maka dengan kanselisasi kiri dan kanan diperoleh $a^{-1} b=b a^{-1}$ sehingga terbukti bahwa $G$ abelian. Menurutmu apakah langkah pembuktian di atas benar? Jika benar berikan alasan jawabanmu dan jika salah berikan penjelasan dan perbaikilah bukti tersebut!

Gambar 2. Masalah untuk mengukur indikator 2

Pada masalah 2, mahasiswa diminta untuk menentukan kebenaran dari suatu pembuktian dan melengkapi pembuktian yang dianggap salah. Permasalahan yang ditawarkan adalah membuktikan bahwa jika $b^{-1} a^{-1} b a=e$, untuk setiap $a, b$ anggota $G$ maka $G$ grup abelian. Dari hasil pengerjaan mahasiswa, sebagian besar mahasiswa keliru dalam melihat kesesuaian antara masalah yang diberikan dengan penyelesaian sehingga keliru dalam memberikan tanggapan atau keliru dalam memberikan penilaian benar atau salah pada suatu pembuktian. Sebagai besar mahasiswa menilai pembuktian tersebut benar, sehingga tidak perlu diperbaiki lagi. Padahal, pembuktian tersebut salah. Karena pada salah satu 
langkah pembuktian yang diberikan dari soal sudah menggunakan konsep grup abelian, yaitu $b^{-1} a^{-1} b a=\left(b^{-1} b\right)\left(a^{-1} a\right)$ sedangkan seharusnya konsep grup abelian itulah yang harus ditunjukkan. Hal ini menunjukkan bahwa mahasiswa masih belum sepenuhnya mampu menilai kebenaran suatu konsep dikarenakan lemahnya mahasiswa dalam memahami suatu konsep yang diberikan.

Lemahnya kemampuan mahasiswa dalam pembuktian matematis selain disebabkan oleh lemahnya pemahaman mahasiswa tehadap konsep yang diperoleh dalam mata kuliah Struktur Aljabar khususnya pada materi grup hingga subgrup, juga disebabkan oleh pola kebiasaan dalam proses belajar mengajar. Pada umumnya, mata kuliah Struktur Aljabar merupakan salah satu mata kuliah yang melibatkan konsepkonsep abstrak. Sedangkan mahasiswa belum terbiasa memahami konsepkonsep matematika abstrak. Sehingga hal ini sangat memungkinkan menjadi penyebab lemahnya kemampuan mahasiswa dalam pembuktian matematis. Hal sejalan juga diungkapkan oleh Lestari (2015) yang menyebutkan bahwa permasalahan yang dihadapi masalah dalam pembuktian matematis diantaranya yaitu pemahaman dalam membaca dan memahami pembuktian matematis, menyajikan bukti kebenaran suatu pernyataan secara sistematis.

Selain itu berdasarkan catatan lapangan, penyebab lain belum maksimalnya hasil kemampuan pembuktian matematis adalah soalsoal latihan yang tersedia pada bahan ajar tidak terlalu banyak. Sehingga mahasiswa tidak terlalu terlatih dalam menyelesaikan soal-soal pembuktian matematis. Sedangkan proses latihan secara berkelanjutan merupakan salah satu cara melatih mahasiswa untuk memiliki kemampuan pembuktian matematis.

Banyakya kelemahan yang ditunjukkan mahasiswa dalam pengerjaan soal tes pembuktian matematis menjadi evaluasi baik bagi mahasiswa selaku pihak yang belajar maupun dosen selaku pihak yang mengajar. Meskipun masih terdapat begitu banyak kelemahan dalam pembuktian matematis, namun penelitian ini dapat dijadikan sebagai langkah awal untuk pengembangan kemampuan pembuktian matematis selanjutnya dengan terus melakukan perbaikan pada bahan ajar struktur aljabar yang digunakan. Namun demikian, kemampuan pembuktian matematis mahasiswa ini telah menunjukkan adanya peningkatkan yang cukup signifikan.

\section{SIMPULAN DAN SARAN}

Berdasarkan hasil penelitian dan pembahasan diperoleh hasil uji hipotesis yang menunjukkan bahwa pembelajaran menggunakan bahan ajar struktur aljabar berbasis pembuktian matematis dapat meningkatkan kemampuan pembuktian matematis dengan bahwa $Z_{0 b s}=9,74>1,645=Z_{0,05}$. Secara umum, skor total kemampuan pembuktian matematis sebesar 44,34 dari skor total yaitu 100 atau sebesar 44,34\% dengan kategori baik. Secara khusus, penggunaan bahan ajar struktur aljabar berbasis pembuktian matematis dapat mengembangkan kemampuan pembuktian matematis pada indikator kemampuan mengkonstruksi bukti meliputi 
penggunaan metode-metode pembuktian dan penggunaan fakta, konsep, dan prinsip matematika sebesar 26,99 dari skor total 50 atau sebesar 53,98\% dengan kategori baik, dan sebesar 17,14 dari skor total 50 atau sebesar 34,70\% dengan kategori baik pada indikator kemampuan membaca suatu pembuktian untuk menentukan kebenaran atau kekeliruannya dengan melihat kesesuaian antara sistem aksioma, premis, atau teorema yang sudah ada serta melengkapi pembuktian.

Kemampuan pembuktian matematis mahasiswa dinilai belum maksimal, namun penggunaan bahan ajar struktur aljabar berbasis pembuktian matematis ini dapat dijadikan salah satu rujukan untuk terus mengembangkan kemampuan pembuktian matematis. Oleh karena itu, penulis menilai tetap perlu dilakukan upaya-upaya perbaikan untuk mengembangkan kemampuan pembuktian matematis. Peneliti menyarankan untuk penambahan soal latihan pada bahan ajar yang dapat mengasah kemampuan pembuktian matematis pada kedua indikatornya, serta melakukan kolaborasi penggunaan bahan ajar dengan model pembelajaran inovatif yang dinilai dapat mengembangkan kemampuan pembuktian matematis, misalnya dengan menggunakan model pembelajaran penemuan terbimbing.

\section{DAFTAR PUSTAKA}

Arnawa, M. (2006). Meningkatkan Kemampuan Pembuktian Mahasiswa dalam Aljabar Abstrak Melalui Pembelajaran Berdasarkan Teori APOS. Disertasi tidak diterbitkan. Bandung:
Universitas Pendidikan Indonesia.

Downs, M. J. \& Downs, M. (2002). Advanced Mathematical Thinking With a Special Reference to Reflection on Mathematical Structure. Dalam L.D. English (eds.). Handbook of International Research in Mathematics Education. Mahwah: Lawrence Erlbaum Associates.

Fadillah, S. \& Jamilah. (2015). Pengembangan Bahan Ajar Struktur Aljabar untuk Meningkatkan Kemampuan Pembuktian Matematis Mahasiswa. Jurnal Ilmiah Pendidikan, Cakrawala Pendidikan, Vol. 35, No.1, 106-113.

Lestari, K. E. (2015). Analisis Kemampuan Pembuktian Matematis Mahasiswa Menggunakan Pendekatan Induktif-Deduktif pada Mata Kuliah Analisis Real. Jurnal Kajian Pendidikan dan Pengajaran, Vol.1, No.2, 128135.

Shelden, A. \& Shelden, J. (2003). Validation of Proof Considered as Texts: Can Undergraduate tell Whether an Argument Proves a Theorem?. Journal for research in Mathematics Education, Vol.34, No.1, 4-36. 
Sugiyono. (2012). Metode Penelitian

Campuran (Mix Method). Bandung: Penerbit Alfabeta.

Thiagarajan, S., Summel, D. S., \& Summel, M. (1974). Instructional Development for Training Teachers of Expectional Children. A Source Book. Bloomington: Center of Innovation on Teaching the Handicapped. Minnepolis: Indian University. 